Journal of Economics and Behavioral Studies

Vol. 4, No. 8, pp. 467-476, Aug 2012 (ISSN: 2220-6140)

\title{
A Study of the Impact of the e-CRM Perspective on Customer Satisfaction and Customer Loyalty-Exemplified by Bank Sinopac
}

\author{
${ }^{*}$ Chun-Chu Liu, Hsing-Chau Tseng, Li-min Chuang, Chien-Min Huang \\ Graduate School Business and operation management, Chang Jung Christian University, Taiwan
}

lcc@mail.cjcu.edu.tw

\begin{abstract}
As the Taiwanese government gradually opens up the country's banking sector in recent years, the number of financial institutions of Taiwan has increased rapidly. Until the end of January 2010, the number of the domestic banks is up to 37, the average number of the customers served in each branch is less than 4,000. As all banks wish to be more competitive in such an environment, new advertising and marketing skills are taken. New banking services and technology are also provided in order to attract more customers. The study aims to discuss the relationship among three aspects including the Electronic Customer Relationship Management, Customer Satisfaction, Customer Loyalty, and we choose Bank Sinopac users as subject. In addition, the following results are concluded by statistics and analysis: 1 . Using e-CRM had obvious on the customer satisfaction and customer loyalty. 2. Customer satisfaction had obvious on the customer loyalty.
\end{abstract}

Keywords: Electronic Customer Relationship Management (E-CRM), Customer Satisfaction, Customer Loyalty, banking, Customer Relationship Management (CRM)

\section{Introduction}

With the government-driven reform and opening-up of Taiwan's banking industry in recent years, there has been a rapid rise in the number of domestic financial institutions. Moreover, Taiwan's joining the World Trade Organization (hereinafter referred to as WTO), signing of the Memorandum of Understanding (MOU), and the recent signing of the Economic Cooperation Framework Agreement (ECFA) are representations of the financial industry being in the face of a competitive environment. As of the end of January 2010, there were a total of 37 domestic banks and 3,158 branches, coupled with up to 5,977 branches of Chunghwa Post Co., credit departments of Farmers' and Fishermen's Associations, foreign banks, life insurance companies, and other institutions. Estimated in line with Taiwan's population of 23 million, each bank offers service to no more than 4,000 people, thus indicating increasing competition among the domestic banks. In order to gain a competitive advantage, each bank has opted for innovative access, marketing, service, and technology to attract customers and further enhance their service quality and contents. Confronted by increasingly unpredictable customer demands and in order to force themselves into the Internet market, the e-commerce war has changed bank platforms from business-oriented into customer-oriented. The traditional Customer Relationship Management (CRM) can no longer cater to the needs of the Internet ecosystem. Therefore, in order to deal with competition arising from the digital economy, the Electronic Customer Relationship Management (e-CRM) has been produced. Because of Internet applications, the search costs for enterprises and individuals' engagements in trade have been reduced. Under the influence of the Internet, product prices have nearly become transparent. Thus, the corporations seriously squeeze profits, and enterprises engage in active efforts to enhance benefit in order to improve competitive product advantage and profitability. After Taiwan's accession to the WTO, the banks, in response to international trends, took to the financial markets and actively developed the CRM to cope with the changing financial environment. Hence, the CRM applications rapidly rose in the banking issues, and customers became important indicators during enterprise setups. Owing to Internet technology, fiber-optic network and wireless network usage increased year by year. After prolonged use, the public developed a sense of dependency for the computer network technology that helped people solved difficulties in life through the fast and convenient computer information, thus many enterprises invested heavily to import Electronic Commerce (EC) for e-actions. Through the importation of electronization, new channels and new products were developed to effectively and quickly achieve the goal of interacting with customers, thereby saving operating costs and easily and efficiently collecting customer-related information. 
E-business has quickly become an integral factor contributing to the success of an enterprise. In order to create more profit and cut down costs, enterprises have one after another-imported electronization. The financial industry, electronic industry, traditional industry, and service industry alike have all gradually imported electronization, thus resulting in fiercer competition among enterprises and the constant introduction of new ideas and tactics to win the biggest source of customers and gain a footing in the highly competitive environment. According to a research conducted by Pepprs \& Rogers (1993), an enterprise is cost for developing a new customer is 10 times as much as the cost for maintaining an existing customer. By inputting $5 \%$ of the marketing costs on the customer, the enterprise's effectiveness can be increased by $60 \%$ to $100 \%$. Thus, customers' repeated spending has become the main profit source for enterprises. To therefore establish customer relationships, constant interaction is essential in order to understand customers' preferences and needs and maintain good relationships with them. In the past, customer interaction depended solely on single visits, while the laboriously collected data lacked collation and integration. However, with the help of technology information systems, the customer information originally scattered in different departments can now be integrated through information technology applications, and the marketing, sales, customer service, and other functions can be combined to provide a customized and effective method for customers. Due to the rapid development of Internet technology, the evolution has led to e-CRM or EC/CRM terms that have emerged one after another. The focus lies in highlighting the important role of information technology in the CRM, but the content is similar to that of CRM, both of which are intended to enhance interaction with customers. The purpose of the banking industry's putting information technology to good use is to create customers, grasp the money flow, and maintain long-term and mutually benefiting partnerships. In fact, the contact point of the interactive channel is the optimal point for understanding the actual demand of customers and their consumption characteristics and is the interactive point for the initiative to provide customer-related knowledge and resources and proper and quick responses to customers' demands. Therefore, this study aimed to adopt the relevance of customer satisfaction, customer loyalty, and other dimensions after the banks' adoption of the e-CRM, which shall serve as a reference for bank operators that are currently constructing e banking or have not yet done so.

\section{Literature Review}

Customer Relationship Management (CRM): CRM is mainly used to obtain accurate information about existing and potential customers, predict and meet customers' demands, and further provide personal and customized services by integrating marketing, sales, services, and various other aspects through information technology. Ittner \& Lackenr (1998) believe that CRM is a type of continuous relationship marketing, the main emphasis of which is to find an enterprise's most valuable customers in order to define the customer groups with different values through the concept of differentiation. Ryals \& Knox (2001) believe that CRM is derived from relationship marketing. Relationship marketing emphasizes the one-to-one marketing approach, but market expansion, channel complexity, product variety, and a significant increase in the number of customers will all hinder the implementation of relationship marketing, specifically as related to the birth of information technology practices in recent years. CRM is a strategy, an action-oriented approach, intended to aid in understanding and changing customer behaviors, thereby enabling new customers to join, existing customers to be maintained, and customers' abilities to profit to be changed. It is an application system -- customers' services, sales, marketing, and support are combined -- which covers three aspects: marketing, sales, and service.

Electronic Customer Relationship Management (E-CRM): According to the definition of Hoffman \& Kashmeri (2000), the difference between e-CRM and CRM lies in e-CRM's integrated marketing, market, and customer service functions, thus achieving continuous operation processes. In view of the existing media used by enterprises, from catalogues, Call Centers, and e-Mail mainly promoted in CRM, to website interaction through Web cooperation, the previous do-it-alone operation mode was changed following the emergence of the Internet. The traditional point of contact underwent internal and external integration of all channels into one, thus enabling customers to have access to a single window where consumer records are retained while maintaining customer interaction and communication. It expand the traditional CRM techniques technologies of new electronic, such as Web, wireless, and voice technologies, and combines them with e-business applications into the overall enterprise CRM strategy. Knowledge for e-CRM is essential because firms must share and create customer knowledge and further predict customer's needs (Bhatt, 2001; Parent and Gallupe, 2000). Understanding customer needs and collecting customer information are critical in the competitive environments (Kim, Suh and Hwang, 2003). Dyche (2001) 
believe that e-CRM can be applied in analysis and data processing and that are many ways to communicate with customers in business dealings, through which customers can have access to a greater variety of information. Enterprises can then continue to collect and analyze information given by customers and create new markets and opportunities based on the information given. Pan \& Lee (2003) believe that e-CRM has contributed to the expansion of the traditional CRM technology and has become a new channel through the Internet integration technology. It has combined the EC provided by enterprises to be applied throughout the enterprises. The concept and use of e-CRM have allowed for the efficient collection of customer-related information.

Customer Satisfaction: The concept of customer satisfaction was first proposed by Cardozo (1965). He interpreted customer satisfaction as: good customer satisfaction will lead to a better reputation, thus enabling customers or consumers to accept other types of products or enhancing their purchase intentions. Customer satisfaction is one of the focused indicators of enterprises. Good products, services, and quality all affect customer satisfaction, so when customers feel "satisfied," they tend to engage in repeated consumption. Ostrom \& Iacobucci (1995) believe that customer satisfaction assessment is a customer's expectation and knowledge of the performance of a product or service thus leading to the determination of the degree of satisfaction, which is the customers' overall assessment of the product price, the product quality, the company's internal operating efficiency and service system, the staff's service attitude, professional knowledge, and ability, the company's overall performance, and the company's closeness to being an ideal company. Oliver (1997) mentioned that the difference between satisfaction from the holistic view and specific customer satisfaction lies in the assessment and judgment after shopping or the emotional response of the most recent transaction experience with the company, rather than pursuing short-term and special exposure-related assessments and emotions.

Customer Loyalty: Jones \& Sasser (1995) defined customer loyalty as a customer's intention to purchase a product or service again in the future. They believe that there are two types of customer loyalties: one is long-term loyalty, which is true loyalty and not subject to change, and the other is short-term loyalty, wherein a customer may choose to leave immediately when he/she finds a better product or service. Bhote (1996) believes that customer loyalty refers to a consumer's satisfaction with the product or service provided by the company and thus the customer is willing to positively advocate about the company. Singh \& Sirdeshmukh (2000) believe that customer loyalty is a behavioral tendency -- the consumer's willingness to continue to maintain relationships with the service provider. Lee \& Cunningham (2001) believe that customer loyalty is the customer's intention to frequently patronize the company that provides the existing services based on the customer's past experiences and future expectations.

\section{Methodology}

Research Framework and Hypotheses: In this study, the relevant literatures of the various dimensions were collated, and the scales proposed by the scholars shall serve as a reference for the research framework and questionnaire design. In this study, the relationships among the e-CRM, customer satisfaction, and customer loyalty dimensions were explored and collated in the Figure 1.

Hypothesis 1: e-CRM produces a positive impact on customer satisfaction.

Hypothesis (H1-1) : The e-CRM technology integration dimensions a positive impact service satisfaction.

Hypothesis (H1-2) : The e-CRM organization support dimension a positive impact on service satisfaction.

Hypothesis ( H1-3): The-CRM environmental pressure dimensions a positive impact on service satisfaction.

Hypothesis ( H1-4) : e-CRM customer knowledge dimensions a positive impact on service satisfaction.

Hypothesis (H1-5) : e-CRM technology integration dimensions a positive impact on product satisfaction. Hypothesis (H1-6) : e-CRM organization support dimension a positive impact on product satisfaction. Hypothesis ( H1-7) : e-CRM environmental pressure dimensions a positive impact on product satisfaction. Hypothesis ( H1-8) : e-CRM customer knowledge dimensions a positive impact on product satisfaction. Hypothesis2: e-CRM produces a positive impact on customer loyalty. Hypothesis (H2-1): The e-CRM technology integration dimension produces a positive impact on customer loyalty 
Hypothesis (H2-2) : The e-CRM organization support dimension a positive impact on customer loyalty. Hypothesis ( $\mathrm{H} 2-3)$ : The-CRM environmental pressure dimensions a positive impact on customer loyalty. Hypothesis (H2-4) : e-CRM customer knowledge dimensions a positive impact on customer loyalty. Hypothesis ( H2-5) : e-CRM technology integration dimension a positive impact on loyalty switch Hypothesis (H2-6) : e-CRM organization support dimension a positive impact on loyalty switch Hypothesis ( H2-7) : e-CRM environmental pressure dimension a positive impact on loyalty switch Hypothesis ( H2-8) : e-CRM customer knowledge dimensions a positive impact on loyalty switch. Hypothesis3: Customer satisfaction produces a positive impact on customer loyalty. Hypothesis (H3-1): Service satisfaction has a positive impact on customer loyalty. Hypothesis (H3-2): The e-CRM product satisfaction a positive impact on customer loyalty. Hypothesis ( H3-3 ): The e-CRM service satisfaction a positive impact on loyalty switch. Hypothesis ( H3-4 The e-CRM product satisfaction a positive impact on loyalty switch.

Figure 1: Research Framework

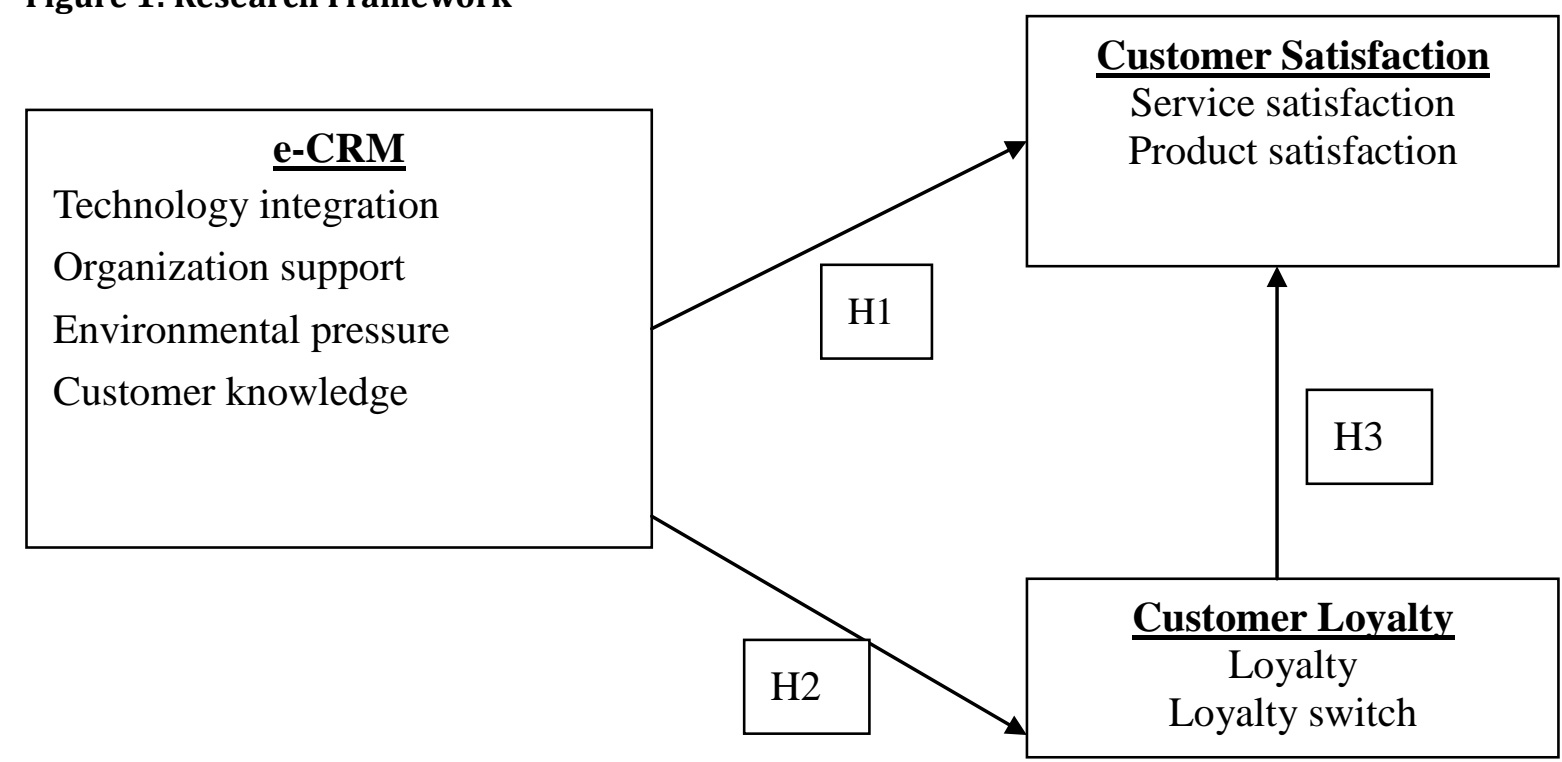

e-CRM: In this study, the definition of Hoffman \& Kashmeri (2000) was adopted. They believe that the difference between e-CRM and CRM lies in e-CRM's integrated marketing, market, and customer service functions, thus achieving continuous and uninterrupted operating processes. In regards to the e-CRM measurement dimension, the definition of Brown (2000) was adopted in this study, which was corrected in reference to the e-CRM related scales developed in relevant literatures and based on the characteristics of the study subjects. The scales of the e-CRM variables consist of 17 questions in total, and the 5-point Likert scale was adopted.

Customer Satisfaction: In this study, the views of Ostrom \& Iacobucci (1995) were adopted. Ostrom \& Iacobucci (1995) believe that customer satisfaction assessment entails a customer's expectation and knowledge of the performance of a product or service thus leading to the determination of the degree of satisfaction, which is the customers' overall assessment of the product price, product quality, the company's internal operating efficiency and service system, the staff's service attitude, professional knowledge, and ability, the company's overall performance, and the company's closeness to being an ideal company. In terms of the measurement of customer satisfaction, the measurement dimensions of Babakus, Bienstock \& Scotter (2004) were adopted. In reference to the customer satisfaction variable measurement by Churchill (1982), a total of 11 questions on the scales of the customer satisfaction variables were used, and the 5-point Likert scale was adopted.

Customer Loyalty: Jones \& Sasser (1995) defined customer loyalty as a customer's intention to purchase a product or service again in the future. They believe that there are two types of customer loyalties: one is long-term loyalty, which is true loyalty and not subject to change, and the other is short-term loyalty, wherein a customer may choose to leave immediately when he/she finds a better product or service. In terms of the measurement of customer loyalty, the measurement dimensions of Parasuraman, Zeithanl \& 
Berry (1996) were adopted. In reference to the customer loyalty variables of Lee \& Cunningham (2001), a total of 13 questions in the scales of the customer loyalty variables were used, and the 5-point Likert scale was adopted.

Sampling Design and Data Analysis Method: Customers who had business dealings with Bank Sinopac were adopted in this study as the study subjects. The scope of the survey covered the customers from southern Taiwan. The purposing sampling method was adopted, and the survey period was from Jan $1^{\text {st }}$, 2011, to Sep 30th, 2011. A total of 500 questionnaire copies were distributed, and the recovery rate reached $85 \%$. Descriptive statistics, correlation analysis, factor analysis, reliability and validity analysis, and regression analysis were adopted in this study as the data analysis methods.

\section{Empirical Analysis}

Descriptive and Statistical Analysis: The results show that the females accounted for the majority of the 426 subjects. There were 238 females, which accounted for $56 \%$ of the total number of subjects, followed by the 188 males, which accounted for $44 \%$ of the total. In terms of age, the 21-30 year-old group comprised the largest set. There were 155 subjects that belonged to this group, which accounted for $36.4 \%$ of the total, and the last in rank was the 51-60 year-old age group. There were 78 subjects that belonged to this group, which accounted for $18.3 \%$ of the total. In terms of education, university (college) comprised the majority. There were 212 subjects that belonged to this group, which accounted for $49.7 \%$ of the total, followed by senior high school (vocational high school). There were 92 subjects that belonged to this group, which accounted for $21.6 \%$ of the total. Finally, there were 42 subjects that belonged to the postgraduate school (or higher), which accounted for $9.9 \%$ of the total. In terms of marital status, the married subjects comprised the largest set. There were 222 married subjects, who accounted for 52.3\% of the total; there were 204 unmarried subjects, which accounted for $47.7 \%$ of the total. In terms of occupation, the freelancers comprised the largest set. There were 152 freelancer subjects, which account for $35.7 \%$ of the total. Finally, there were 62 military personnel, civil servants, and teachers, which accounted for $14.5 \%$ of the total. In terms of monthly income, the $\$ 18,000 \sim 36,000$ group comprised the largest set. There were 219 subjects that belonged to this group, which accounted for $51.5 \%$ of the total; finally, 63 subjects belonged to the $\$ 18,000$ or lower group, which accounted $14.8 \%$.

Validity and Reliability Analysis: Concerning the three dimensions of e-CRM, customer satisfaction, and customer loyalty in this study, the KMO, Kaiser-Meyer-Olkin, measure of sampling adequacy values all exceeded 0.8. In addition, in the Bartlettf's spherical test, the P-values of the three dimensions all reached significance, thus denying the null hypothesis (i.e. the hypothesis that the net correlation matrixes among the variables were not unit matrixes was denied). This finding indicates that common factors exist among the correlation matrixes of the population. It can therefore be inferred that this study is suitable for factor analysis. The KMO values and Bartlett spherical test values are as shown in the table 1.

Table 1: The KMO values and Bartlett spherical test values

\begin{tabular}{lll}
\hline Dimension & $\begin{array}{l}\text { KMO, Kaiser-Meyer-Olkin measure of } \\
\text { sampling adequacy }\end{array}$ & $\begin{array}{l}\text { Bartlett } \\
\text { (P-Value) }\end{array}$ \\
\hline e-CRM & 0.898 & $0.000^{* * *}$ \\
Customer satisfaction & 0.905 & $0.000^{* * *}$ \\
Customer loyalty & 0.913 & $0.000^{* * *}$ \\
\hline
\end{tabular}

Note: ${ }^{*}$ Represents $\mathrm{P}<0.05$; $^{* *} \mathrm{P}<0.001$; $^{* * *} \mathrm{P}<0.0001$

The Factor Analysis of e-CRM: In this study, the principal component analysis was adopted for the factor analysis of the e-CRM dimensions. According to the analysis results, after extracting 4 factors from the e-CRM dimensions, namely the Technology integration dimension, Organization support dimension, Environmental pressure dimension, and Customer knowledge dimension, the eigenvalues were 6.583, $1.899,1.3451 .001$, and 0.798 ,respectively. The cumulative variance reached $63.764 \%$, while the respective factor loadings were all greater than 0.4 and close to 0.5 . 
The Factor Analysis of Customer Satisfaction: In this study, the principal component analysis was adopted for the factor analysis of the customer satisfaction dimensions. According to the analysis results, after extracting 2 factors which were named "service satisfaction" and "product satisfaction" based on the questions, the eigenvalues were 6.203 and 1.148 , respectively, the cumulative variance reached $66.295 \%$, and the respective factor loadings were all greater than 0.5 .

The Factor Analysis of Customer Loyalty: In this study, the principal component analysis was adopted for the factor analysis of the customer loyalty dimensions. According to the analysis results, after extracting 2 factors which were named "loyalty" and "loyalty switching" based on the questions, the eigenvalues were 6.285 and 1.345 ., respectively, the cumulative variance reached $58.262 \%$, and the respective factor loadings were all greater than 0.5 .

Reliability Analysis: According to the results of the e-CRM reliability analysis, e-CRM can be divided into four dimensions. The Cronbach's $\alpha$ values of the dimensions were $0.873,0.723,0.609$, and 0.700 , respectively. The correlation coefficient distributions of the sub-items and total items were between 0.389 and 0.780. According to the results of the customer satisfaction analysis the Cronbach's $\alpha$ value of the dimensions was 0.877 and 0.881 , respectively. The correlation coefficient distributions of the sub-items and total items were between 0.637 and 0.783 . According to the results of customer satisfaction, the Cronbach's $\alpha$ values of the dimensions were 0.902 and 0.784 , respectively. The correlation coefficient distributions of the sub-items and total items were between 0.473 and 0.731 .

The Regression Analysis of e-CRM on Overall Satisfaction: According to the results of the analysis (Table 2), e-CRM produced a significant impact on overall satisfaction ( $\mathrm{F}=19.865, \mathrm{P}=0.000$, and $\mathrm{DW}$ value of 1.615). The technology integration dimension produced a significant impact on the service satisfaction, and the P-value was $0.000<0.001$. Thus, Hypothesis H1-1 is supported. This finding indicates that the bank's technology integration provision contributed to the upward improvement of service satisfaction. The organization support dimension produced a significant impact on the service satisfaction, and the $\mathrm{P}$-value was $0.008<0.01$. Thus, Hypothesis $\mathrm{H} 2-1$ is supported. This finding indicates that, in terms of organization support channels, the bank contributed to the upward improvement of service satisfaction. However, the environment pressure dimension and customer knowledge dimension did not produce significant impacts on service satisfaction, and the P-values were 0.107 and $0.309>0.05$, respectively. Thus, Hypotheses H1-3 and H1-4 are not supported. This finding indicates that the environment pressure dimension and customer knowledge dimension had no effect on the enhancement of the service satisfaction.

Table 2: Regression analysis of e-CRM on overall satisfaction

\begin{tabular}{lllll}
\hline Independent variable & e-CRM & & & \\
\cline { 2 - 5 } Dependent variable) & $\begin{array}{l}\text { Technology } \\
\text { integration } \\
\text { dimension }\end{array}$ & $\begin{array}{l}\text { Organization } \\
\text { support } \\
\text { dimension }\end{array}$ & $\begin{array}{l}\text { Environment } \\
\text { pressure } \\
\text { dimension }\end{array}$ & $\begin{array}{l}\text { Customer } \\
\text { knowledge } \\
\text { dimension }\end{array}$ \\
\hline Service satisfaction & $0.347^{* * *}$ & $0.171^{* * *}$ & 0.102 & -0.078 \\
Degree of freedom & 4 & & & \\
Adjusted $\mathrm{R}^{2}$ & 0.228 & & & \\
F value & $18.965^{* * *}$ & & & \\
Durbin-Watson value & 1.815 & & & \\
\hline
\end{tabular}

Note:* represents $\mathrm{p}<0.05 ;^{* *} \mathrm{p}<0.01 ;^{* * *} \mathrm{p}, 0.001$

The Regression Analysis of e-CRM on Product Satisfaction: According to the results of the analysis (Table 3), e-CRM produced a significant impact on service satisfaction ( $\mathrm{F}=45.091, \mathrm{P}=0.000$, and a DWvalue of 1.907). The technology integration dimension produced a significant impact on product satisfaction, and the P-value was $0.000<0.001$. Thus, Hypothesis H1-5 is supported. This finding indicates that, in terms of technology integration provision, the bank contributed to the upward improvement of customer product satisfaction. However, the organization support dimension, Environment pressure dimension, and 
Customer knowledge dimension produced no significant impacts on product satisfaction, and the P-values were 0.181, 0.816, and 0.339>0.05, respectively. Thus, Hypotheses H1-6, H1-7, and H1-8 are not supported. This finding indicates that the organization support dimension, environment pressure dimension, and customer knowledge dimension did not have an effect on the enhancement of product satisfaction.

Table 3: Regression analysis of e-CRM on product satisfaction

\begin{tabular}{lllll}
\hline \multicolumn{1}{c}{ Independent } & e-CRM & & & \\
\cline { 2 - 5 } $\begin{array}{l}\text { vependent } \\
\text { variable }\end{array}$ & $\begin{array}{l}\text { Technology } \\
\text { integration } \\
\text { dimension }\end{array}$ & $\begin{array}{l}\text { Organization } \\
\text { support } \\
\text { dimension }\end{array}$ & $\begin{array}{l}\text { Environment } \\
\text { pressure } \\
\text { dimension }\end{array}$ & $\begin{array}{l}\text { Customer } \\
\text { knowledge } \\
\text { dimension }\end{array}$ \\
\hline Product satisfaction & $0.348^{* * *}$ & 0.081 & 0.015 & -0.061 \\
Degree of freedom & 4 & & & \\
Adjusted $\mathrm{R}^{2}$ & 0.399 & & & \\
F value & $42.291^{* * *}$ & & & \\
Durbin-Watson value & 1.869 & & & \\
\hline
\end{tabular}

Note:* represents $\mathrm{p}<0.05 ;^{* *} \mathrm{p}<0.01 ;^{* * *} \mathrm{p}, 0.001$

The Regression Analysis of e-CRM on Customer Loyalty: According to the results of the analysis (Table 4), e-CRM produced a significant impact on overall loyalty ( $\mathrm{F}=24.986, \mathrm{P}=0.000$, and a DWvalue of 1.665 ). The technology integration dimension produced a significant impact on customer loyalty, and the P-value was $0.000<0.001$. Thus, Hypothesis H2-1 is supported. This finding indicates that the bank's technology integration provision contributed to the upward improvement of customer loyalty. The organization support dimension produced a significant impact on customer loyalty, and the P-value was $0.001<0.01$. Thus, Hypothesis H2-2 is supported. This finding indicates that, in terms of organization support channels, the bank contributed to the upward improvement of customer loyalty. The environment pressure dimension produced a significant impact on customer loyalty, and the P-value was $0.023<0.05$. Thus, Hypothesis H2-3 is supported. This finding indicates that, in terms of environment pressure channel, the bank contributed to the upward improvement of customer loyalty. The customer knowledge dimension produced a significant impact on customer loyalty, and the P-value was $0.009<0.01$. Thus, Hypothesis $\mathrm{H} 2-4$ is supported. This finding indicates that, in terms of environment pressure and customer knowledge channel, the bank contributed to the upward improvement of customer loyalty.

Table 4: Regression analysis of e-CRM on customer loyalty

\begin{tabular}{|c|c|c|c|c|}
\hline \multirow{2}{*}{$\begin{array}{l}\text { Independent } \\
\text { variable } \\
\text { Dependent } \\
\text { variable }\end{array}$} & \multicolumn{4}{|l|}{ e-CRM } \\
\hline & $\begin{array}{l}\text { Technology } \\
\text { integration } \\
\text { dimension }\end{array}$ & $\begin{array}{l}\text { Organization } \\
\text { support } \\
\text { dimension }\end{array}$ & $\begin{array}{l}\text { Environment } \\
\text { pressure } \\
\text { dimension }\end{array}$ & $\begin{array}{l}\text { Customer } \\
\text { knowledge } \\
\text { dimension }\end{array}$ \\
\hline Customer loyalty & $0.418^{* * *}$ & $0.215^{* *}$ & 0.141 & $0.193^{* *}$ \\
\hline Degree of freedom & 4 & & & \\
\hline Adjusted $\mathrm{R}^{2}$ & 0.271 & & & \\
\hline F value & $25.896^{* * *}$ & & & \\
\hline Durbin-Watson value & 1.785 & & & \\
\hline
\end{tabular}

Note:* represents $\mathrm{p}<0.05$; $^{* *} \mathrm{p}<0.01$; $^{* * *} \mathrm{p}, 0.001$

The Regression Analysis of e-CRM on Loyalty switching: According to the results of the analysis (Table 5), e-CRM produced a significant impact on loyalty switching ( $\mathrm{F}=24.986, \mathrm{P}=0.000$, and a DWvalue of 
1.790). The technology integration dimension produced a significant impact on loyalty switching, and the P-value was $0.000<0.001$. Thus, Hypothesis H2-5 is supported. This finding indicates that, in terms of technology integration provision, the bank contributed to the enhancement of customer loyalty switching. The environment pressure dimension produced a significant impact on the loyalty switching, and the P-value was $0.000<0.001$. Thus, Hypothesis H2-7 is supported. This finding indicates that, in terms of the provision of environment pressure channels, the bank contributed to the upward improvement of customer loyalty switching. The customer knowledge dimension produced a significant impact on loyalty switching, and the P-value was $0.009<0.01$. Thus, Hypothesis H2-8 is supported. This finding indicates that, in terms of environment pressure and customer knowledge channel, the bank contributed to the enhancement of customer loyalty. However, the organization support dimension did not produce a significant impact on loyalty switching, and the P-value was 0.565 $>0.05$. Thus, Hypothesis H2-6 is not supported. This finding indicates that, in terms of organization support channel provision, the bank did not contribute to the enhancement of customer loyalty switching.

Table 5: Regression analysis of e-CRM on loyalty switching satisfaction

\begin{tabular}{|c|c|c|c|c|}
\hline Independent & e-CRM & & & \\
\hline $\begin{array}{l}\text { variable } \\
\text { Dependent } \\
\text { variable }\end{array}$ & $\begin{array}{l}\text { Technology } \\
\text { integration } \\
\text { dimension }\end{array}$ & $\begin{array}{l}\text { Organization } \\
\text { support } \\
\text { dimension }\end{array}$ & $\begin{array}{l}\text { Environment } \\
\text { pressure } \\
\text { dimension }\end{array}$ & $\begin{array}{l}\text { Customer } \\
\text { knowledge } \\
\text { dimension }\end{array}$ \\
\hline $\begin{array}{l}\text { Loyalty switching } \\
\text { satisfaction }\end{array}$ & $0.339 * * *$ & 0.037 & $0.361^{* * *}$ & $0.331^{* * *}$ \\
\hline Degree of freedom & 4 & & & \\
\hline Adjusted R2 & 0.252 & & & \\
\hline F value & $19.664^{* * *}$ & & & \\
\hline Durbin-Watson value & 1.87 & & & \\
\hline
\end{tabular}

Note:* represents $\mathrm{p}<0.05 ;^{* *} \mathrm{p}<0.01 ;{ }^{* * *} \mathrm{p}, 0.001$

The Regression Analysis of Customer Satisfaction on Customer Loyalty: According to the results of the analysis (Table 6), customer satisfaction produced a significant impact on customer loyalty $(\mathrm{F}=149.586$, the P-value was 0.000 , and a DWvalue of 1.660). Overall satisfaction produced a significant impact on customer loyalty, and the P-value was $0.000<0.001$. Thus, Hypothesis $3-1$ is supported. This finding indicates that service customer satisfaction with the bank contributed to the enhancement of customer loyalty. Product satisfaction produced a significant impact on customer loyalty, and the P-value was $0.000<0.001$. Thus, Hypothesis $3-2$ is supported. This finding indicates that customer satisfaction with the bank products contributed to the enhancement of the customer loyalty switching.

Table 6: Regression analysis of customer satisfaction on customer loyalty

\begin{tabular}{lll}
\hline Independent variable & Customer satisfaction & \\
\cline { 2 - 3 } Dependent variable & Service satisfaction & Product satisfaction \\
\hline Customer loyalty & $0.442^{* * *}$ & \\
Degree of freedom & 2 & \\
Adjusted R2 & 0.512 & \\
F value & $147.557^{* * * *}$ \\
Durbin-Watson value & 1.75 & \\
\hline
\end{tabular}

Note:* represents $\mathrm{p}<0.05$; $^{* *} \mathrm{p}<0.01 ;^{* * *} \mathrm{p}, 0.001$

The Regression Analysis of Customer Satisfaction on Loyalty switching: According to the results of the analysis (Table 7), customer satisfaction produced a significant impact on customer loyalty. ( $F=55.379$, 
the P-value was 0.000 , and a DWvalue of 1.539). Service satisfaction did not produce a significant impact on loyalty switching, and the P-value was $0.143>0.001$. Thus, Hypothesis 3-3 is not supported. This finding indicates that service satisfaction with the bank did not contribute to the enhancement of customer loyalty switching. Product satisfaction produced a significant impact on loyalty switching, and the P-value was $0.000<0.001$. Thus, Hypothesis $3-4$ is not supported. This finding indicates that customer satisfaction with the bank products contributed to the enhancement of customer loyalty switching.

Table 7: Regression analysis of customer satisfaction on loyalty switching

\begin{tabular}{lll}
\hline $\begin{array}{l}\text { Independent variable } \\
\text { Dependent variable }\end{array}$ & Customer Satisfaction & \\
\cline { 2 - 3 } Loyalty switching & 0.111 & Product satisfaction \\
Degree of freedom & 2 & $0.456^{* * *}$ \\
Adjusted R2 & 0.279 & \\
F value & $54.389^{* * *}$ & \\
Durbin-Watson value & 1.56 & \\
\hline
\end{tabular}

Note:* represents $\mathrm{p}<0.05$;** $^{* *}<0.01$; $^{* * *} \mathrm{p}, 0.001$

\section{Conclusion}

According to the analysis results, in the face of the impacts of the various e-CRM dimensions on customer satisfaction, the customers positively recognized the bank's provision of the communication and transaction dimensions. This finding indicates that, in terms of customer communication channels and transaction channels, Citibank managed to maintain a close relationship with its customers in terms of system operation and interaction with the bank. However, the bank's provision of distribution and information produced no significant impact on the customers. After exploring the reasons, it was found that Citibank's transaction platform (such as ATM) setup is unlike other banks, which engage in cooperation with different operators, thereby resulting in the customers' inability to access the system when they needed it, the most. In terms of information, the relevant information provided by the bank did not produce a significant impact on customer satisfaction. This finding indicates that, when the bank disseminates information to its customers, the information received lacked appeal due to the lack of clarity. This result coincides with the views of scholars Srinivas \& Bollampally (2007) that customer satisfaction is affected by the e-CRM applications. Hence, the bank needs to provide more diverse functions to attract customers. The various e-CRM dimensions in the face of customer loyalty produced significant impacts. This finding indicates that the communication dimension, transaction dimension, distribution dimension, and information dimension all contributed to the upward improvement of customer loyalty. However, the transaction dimension did not produce a significant impact on loyalty switching. This finding indicates that with the fewer transaction channels provided by the bank preventing them from finding other alternative transaction systems when they needed it resulted in the impacts from the customers' switched use. This finding coincides with the views of scholars Dyche (2001) and Tanveer (2009) that customer loyalty is affected by the e-CRM applications. Therefore, by implementing more comprehensive transaction channel setups in the bank, the customers can have quick access to them and the impacts of the switch can be reduced. The customer satisfaction produced a significant impact on customer loyalty, thus indicating that overall customer satisfaction with the bank and customer product satisfaction contributed to the loyalty to the company and the enhancement of switched loyalty. However, overall satisfaction produced no significant impact on switched loyalty, thus indicating that there is stillroom for improvements in terms of the overall services provided by the bank. This finding coincides with the views of Jill \& Joffre (2008) that customer loyalty is affected by the e-CRM applications. Therefore, the bank needs to reinforce areas of customer dissatisfaction in order to stabilize customer loyalty to the company.

\section{References}

Babakus, E., Bienstock, C. C. \& Van-Scotter, J. R. (2004). Linking perceived quality and customer satisfaction to store traffic and revenue growth. Decision Sciences, 35(4), 713-737.

Bhatt, G. D. (2001). Building a customer-focused Internet site, In J, DeGross(ed), Proceeding of Seventh 
Americas Conference on Information System, Boston, Omnipress, 908-912

Bhote, K. R. (1996). Beyond Customer Satisfaction to Customer Loyalty : The Key to Greater Profitability. American Management Association, New York.

Brown, S. (2000). Customer Relationship Management- A Strategic Imperative in the world of e-Business. John Wiley \& sons Canada, Ltd.

Cardozo, R. N. (1965). An Experimental Study of Consumer Effort, Expectation and Satisfaction. Journal of Marketing Research, 2, 244-249.

Churchill, G. A. \& Suprenaut, J. C. (1982). An investigation into the determinants of consumer satisfaction. Journal of Marketing Research, 19(4), 491-504.

Dyche, J. (2001). The CRM Handbook: A Business Guide to Customer Relationship Management, Addison-Wesley, Boston, MA.

Hoffman, T. \& Kashmeri, S. (2000). Coddling the customer. Computerworld, 34(50), 58-61.

Ittner, C. \& Larcker, D. (1998). Are non-financial measures leading indicators of financial performance? an analysis of customer satisfaction. Journal of Accounting Research, 36, 1-35.

Jill, S. \& Joffre, S. (2008). The effects of brand credibility on customer loyalty. Journal of Retailing and Consumer Services, 15(3), 179-193.

Jones, T. 0. \& Sasser, W. E. (1995). Why Satisfied Customers Defect. Harvard Business Review, 73 (6), 88-99.

Kim, J., Suh, E., \& Hwang, H. (2003). A model for Evaluating the effectiveness of CRM using the balance scorecard. Journal of interaction marketing, 17(2), 5-19.

Lee, M. \& Cunningham, L. F. A. (2001). Cost / Benefit Approach to Understanding Service Loyalty. Journal of Services Marketing, 15(2), 113-130.

Oliver, R. L. (1997). Satisfaction: A behavioral perspective on the consumer. New York: Irwin/McGraw-Hill.

Ostrom, A. \& Iacobucci, D. (1995). Consumer tradeoffs and the evaluation of services. Journal of Marketing, $59,17-28$.

Pan, S. L. \& Lee, J. N. (2003). Using e-CRM for a unified view of the customer. Communications of the ACM, 46(4), 95-99.

Parent, M. \& Gallupe, R. B. (2000). Knowledge creation in focus groups: Can group technologies help? Information \& Management, 38 (1), 47-58.

Parasuraman, A., Zeithaml, V. A. \& Berry, L. (1996). The Behavioral Consequence of Service Quality. The Journal of Marketing, 60(2), 31-46.

Pepprs, D. \& Rogers, M. (1993). The one to One Future, Building Relationship One Customer at a Time, New York: Currency Doubleday.

Ryals, L. \& Knox, S. (2001). Cross-Functional Issue in the Implementation of Relationship Marketing Through Customer Relationship Management. European Management Journal, 19(5), 534-542.

Singh, J. \& Sirdeshmukh, D. (2000). Agency and trust mechanisms in consumer satisfaction and loyalty judgments. Journal of the Academy of Marketing Science, 28(1), 150-167.

Srinivas, A. \& Bollampally, K. (2007). Benefits of e-CRM for Banks and their Customers. Unpublished doctoral dissertation, University of Technology, Lulea.

Tanveer, A. (2009). Electronic Customer Relationship Management in Online Banking. Unpublished doctoral dissertation, University of Technology. 